\title{
Graham Greene and the Issue of Obsessive Love: The Critical Analysis of the End of the Affair
}

\author{
Alidou Razakou Ibourahima Boro \\ University of Parakou, Benin Republic \\ Mastazakou5@yahoo.fr
}

\begin{abstract}
Nowadays, human beings' relationships take many forms. People are either parents, friends, colleagues, partners, lovers etc. As far as lovers are concerned, we sometimes observe excesses in their interactions. However, not everybody experiences love in the same way. Love, for some is joy, happiness while other people regard it as source of problems and sufferance. In Corneille's Le Cid, Rodrigue and Chimène are paralyzed by love and suffering, while Romeo and Juliette get to the capital sacrifice for their intensive and polemical love affair in Shakespeare's Romeo in Juliette. This study aims at exploring the concept of obsessive love and its consequences through the characters of Graham Green's The End of the Affair. To succeed in this study apart from books on the selected topic, I have used psychoanalysis as literary theory to access the issue. I examined the difference between obsessive love and true love. Of the results I came up with I can briefly say but a few that obsession can be destructive namely for the obsessed. It can also negatively affect the other members of the family tissue. Obsessive love unfortunately often replaces true love. Ways and means are suggested to cope with any sorts of love.
\end{abstract}

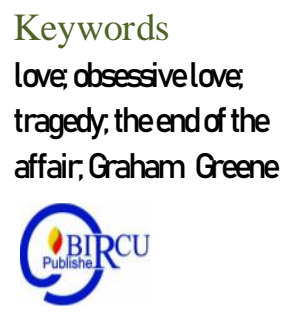

\section{Introduction}

"Well, mother?"

"Well my son?"

She sat in the rocking chair, feeling somehow hurt and humiliated, for his sake.

"Do you like her?"

"Yes, came the slow answer.

She's shy yet, mother. (Lawrence 1913)

Human beings' feeling depends on the kind of people they are. The issue of feeling is individual and it is hard to measure it physically. Therefore, the above statement from D. H. Lawrence shows one of the love a young can have for his beloved in Sons and Lovers. Anyway, the concerns of love around the world are mainly about a partnership between people that have decided to stay or live together and forever. Sometimes, love becomes an obligation mostly when the lovers have true love for each other. In this case, each partner is ready for any sacrifice for the good of the couple. On the other side, love can be just like a business. The main aim in this case is how to make the maximum of profit from the partner.

In fact, love is a matter of heart or belief since sometimes we do not know why we hate or love our neighborhood. That is why Graham Green had decided to depict through his fictional work the dimensions of love. He even, in view of its sacred aspect, shows how love systematically and extremely generate hate. The End of Affair of Mr. Green foregrounds people's over feeling and at the same time draws our attention on the deal carry out by the socalled lovers or the real lover. 
This research work is a real fictional one. However the readers or all scholars can grasp it as a vivid experience and afterward apply its useful aspects to the future generation or implement the gist of the following findings in their real life so that avoid social relations pitfalls and accordingly foresee silent war et social struggles. It can also help the very Youngers around the world to discover the underneath or degree of love throughout human beings' relationship. On the account of outline, this study first focuses on the words etymologies and clarifies love concepts. It also provides the natural force drives

\section{Review of Literature}

\subsection{Etymology of Love Definition and in the Novel}

Etymologically, the word Love comes from Old English and Middle English. From Old English lufu and from Middle English luve which means a strong or profound or caring affection toward someone. I think that love can well defined as one of the most profound feeling or emotions people experience as humans. It is an uncontrolled feeling you have for somebody or for something ${ }^{1}$. According to the Advanced Oxford Dictionary love is:

a strong feeling of deep affection for somebody/something, especially a member of your family or a friend a mother's love for her children love of your country He seems incapable of love.

For the Webster's Beginning Dictionary ${ }^{2}$, to love is to like too much. In fact, in the light of the first definition, love is a great sensitivity of affection for people or everything. As a human being, you can have a special feeling for your father, mother, children or your partner etc. Love is such a part of life that is in demand by every creature on this earth who survive in society let it be mammals, reptiles, animals or any other. This definition is completed by the second definition stressing on the fact that love is to like too much. In the topic under study, love is depicted as fanatical issue. However, wherever there is love there is hate. The Webster's Beginning Dictionary ${ }^{3}$ defines hate as a deep and bitter dislike. This is totally the opposite of love. Since what is bitter is distractive and far from unifying people. To hate someone or something is to feel aversion towards that person or that thing. This dual opposition in concept is present in the novel under study. So, as a result hate meaning as resistance word love, too much dislike to something or somebody since people decide to love, they have beforehand dislike another.

The opposing themes of love and hate run throughout The End of the Affair as Graham Greene (October 2nd, 1904-April 3rd, 1991) sets them up to shed light on each other. That is why, the Mr. Green claims "For why should I have spoken to him?"4 Therefore, this question of the narrator has many dimensions and foreground manifold clarification in the matter of love and hate. Ultimately, he demonstrates that hate can be the surprising precursor to love. In The End of the Affair, Graham stated that if hate was not too large a term to use in relation to any human being ${ }^{5}$. At the same time, he depicts the cruel realities often associated with love and hate. After all, Sarah chooses love (divine) and dies, but Bendrix chooses hate (earthly) and is still alive at the end of the novel. One of the main protagonist of the novel,

\footnotetext{
${ }^{1}$ Tetty Betty. "Love" in English for Students, n.d., https://www.english-for-students.com/love.2.html (consulted on August 2, 2018 at 10 a.m.)

2 Webster's Beginning Dictionary, 1980, United States of America

3 Ibid.

${ }^{4}$ Graham Greene, The End of the Affaire, p. 1.

${ }^{5}$ Ibid.
} 
Sarah is Henry's wife and Bendix's lover. Her love relationship with Bendrix is complicated. She is hesitant to talk of their love when for Bendix is somehow surprising, she is married but she sometimes confess by saying that she deeply loves Bendrix. She seems to find in Bendrix what she is missing in her marriage with Henry. She vows to God that she will be virtuous if she will save Bendrix. This shows how fanatic her love is for Bendrix on the disadvantage of her own husband. Such a thing show the blindness of love because Maurice Bendrix is an unreliable narrator and a selfish, immature, insensitive, and cynical man. $\mathrm{He}$ is a moderately successful writer who met Sarah Miles while doing background research on her husband for a novel he wanted to write.

A closer reading of the novel under study by Mr. Greene allow me to distinguish two kinds of love throughout his fictional work. There are divine love, which is selfless; and the one related to romantic love, which is selfish and can easily turn to hate. Bendrix as an exceptional character of The End of the Affaire knows only romantic love, and he knows it only for Sarah.

\subsection{Divine or Devil Love in the End of the Affaire}

In the real life, divine love is the most important thing that every people must have. For this reason, Mr. Greene portrayed through his fictional work love dimensions. For Pope Benedict XVI, during the commemoration of World Youth Day 2008 in Australia, he claims:

Authentic love is obviously something good. When we love, we become most fully human. Nevertheless, people often consider themselves loving when actually they are possessive or manipulative. People sometimes treat others as objects to satisfy their own needs ${ }^{6}$.

The above explanation of love that at the first glance is not far from God conception but at the same proves the issues of mental trouble and even everything concerning human beings social problem. For E. E. Cummings, Love is "the voice under all silences, the hope which has no opposite in fear; the strength so strong mere force is feebleness: the truth more first than sun, more last than star... "' In The End of Affaire, there is a sacrifices romantic love for divine love. Although she began the affair in pursuit of romantic love, even at the cost of her morality, she is surprised to find herself giving it up to fulfill a desperate promise made to God sacrificing the affair leads Sarah to the other kind of love presented in the novel, divine love. After an intense spiritual struggle to truly give up her romance with Bendrix, she finds herself at peace because she has accepted the love of God. She finds that this love renews her, whereas her love for Bendrix was sinful and unhealthy. In fact, she concludes that her love for Bendrix was merely a stop on the way to the divine love that awaited her. That is the reason why, in her diary, she writes:

Did I ever love Maurice as much before I loved you? Or was it you I really loved all the time? For he hated in me the things you hate. He was on your side all the time without knowing it. You willed our separation, but he willed it too. He worked for it with his anger and his jealousy, and he worked for it with his love. For he gave so much love and I gave him so much love that soon there wasn't anything left, when we'd finished, but You.

In fact, Sarah at a given time, in her life was very confused. Therefore, as a human being, she is right since despite the importance of love in every community, love itself has limit and deserve self-control. What Sarah wrote in her diary is true because love involves

\footnotetext{
${ }^{6}$ Willis Parker. "Love quotes", July 24th, 2018 , https://en.wikiquote.org/wiki/love (consulted on August 2 , 2018 at $10 \mathrm{AM}$

${ }^{7}$ Ibid.
} 
death, suicide, rob, jealousy, slander, hypocrisy, regret, fear, distrust, trust, spiritual marriage, God blessing, peace, war, struggle, fight, wealthy, etc... For Mr. Greene, God love is a permanent question and witnesses through Sarah attitude. People are different from the Almighty, and then they must pay attention because love is not the synonym of killing. In the End of the Affaire, God love is the issue this permanent question. In this way, there is a clash of hate through the mental attitude of the lover who is Sarah, author of this above claiming. Consciously or unconsciously, an internal voice pushes her to decide her goal. Such a behaviour is not very from True love of God's attendance in people's life and it is light that Mr. Greene states: "It is convenient, it is correct according to the rule of craft to begin just there, but if I had believed then in God," Anyway, as whenever we call everything related to the trustworthy "God", we accordingly evoke also the true love to God. In the light of our topic under study and while taking into account God relationship with human being, it is clear that love is before anything divine. Whether or not, they are aware of it, the divine plays a role in the characters' lives. Sarah prays to God in a panicked moment, pleading for Bendrix's life and promising to abandon her immoral ways in return. Sarah says,

Dear God, I said - Why dear? Why dear? . . . I shut my eyes tight, and I pressed my nails into the palms of my hands until I could feel nothing but the pain, and I said, I will believe. Let him be alive, and I will believe . . . and then he came in at the door and he was alive, and I thought now the agony of being without him starts.

In the count of God, there is no lie and believe in divine love or having divine love, is to believe also in God since the achievement of everything around the world depend on him. When Sarah walks into the room, she is convinced that her prayer has saved him and she makes good on her promise. For Sarah, this incident is unquestionably a moment of divine intervention. The spiritual struggle that follows is also an example of the divine shaping her life. She realizes that she cannot attain spiritual peace alone, and she submits to the will of God and feels the change in her life.

\section{Discussion}

\subsection{Romantic or Fake love in Mr. Greene's The End of the Affaire}

To love is to have strong affection or deep tender feeling for someone or for something; to be very fond of; to find pleasure in. In romantic aspect, it is a strong feeling or affection for somebody that you are sexually attracted to. That is the reason why, most of the time, we hear people say: "We are in love!"; "She was in love with"; "They fell in love with each other"; etc. Bendrix knows only romantic love, and he knows it only for Sarah. After he ends their relationship, he does not seek a new woman for his life. Instead, he alternates between love and hate for her. When they are involved, he loves her, but when she stops seeing him, he hates her. Then when he thinks he has a chance to win her back, he loves her again. When she dies, he claims to love her, but his actions tell a different story. His love is so confused by romantic selfishness that he ignores what he can infer about her burial wishes and insists that she be cremated, which according to Catholic faith, would be unpleasing to the God who took her from him. According to Raoufzadeh (2019), in Forough's poetry, the quality of love, its existence and its positive or negative meaning depended largely on the lover and beloved. If they were true and sincere in their love, it would represent itself truly and positively. The true and real face of love was shown and showed by a true lover. 
a. Sarah Miles's Obsession with Mr. Bendrix

In the light of the theme under study and while taking into consideration the word "obsession" meaning, there is no much difference between it and Sarah's ones. We divine love know what has made Sarah obsessed with Maurice Bendrix. Secrets, lies and misunderstandings make up the fabric of The End of the Affair. Of course, the fundamental secret is the affair itself: "I love Maurice more than I did in 1939" and "I do love Henry in my shabby way" declares Sarah. Then, Throughout Sarah psychology and the way she reacts, romantic love is related the poverty while divine love is the starvation or haven. It is neither the first nor the last extramarital affair for Sarah Miles. Her nature impels her to seek a kind of spiritual fulfillment that her husband has never supplied. She is a hopeless romantic, and in her mind, her husband is a bore:

Dear Henry.' So, 'Dear Henry,' I wrote, 'I'm afraid this will be rather a shock to you, but for the last five years I've been in love with Maurice Bendrix. For two years, nearly we have not seen each other or written but it does not work. I can't live happily without him, so I have gone away. ${ }^{9}$

Her obsession starts when she met Maurice Bendrix in party and fall in love with him. After that it noteworthy to point out her obsessional idea when one day she calls him although she is living with Henry:

This is Sarah. Did you get my message?

'Oh, I was going to ring you, but I had to finish an article. By the way, I don't think I've got your number now. It's in the book, I suppose?'

'No. Not yet. We're changed. It's Macaulay 6204. I wanted to ask you something' 'Yes?'

'Nothing very dreadful. I wanted to have lunch with you, that's all.'

'Of course, I' be delighted. When?'

'You couldn't manage tomorrow?'

'No. Not tomorrow. You see, I've simply got this article ...' 'Wednesday?'10

She gives as an explanation of living Henry: "You needn't be so scared. Love does not end. Just because we don't see each other..."11 Sarah grows to believe this, and her narrative - which is openly religious, deeply personal, and, as Bosco phrases it, "sometimes hysterical"-makes explicit the connection between sexual experience and religious love. She wishes for the total annihilation of the body after death, writing, "If I were to invent a doctrine it would be that the body was never born again, that it rotted with last year's vermin." 12 Only after thinking about her sexual relationship with Bendrix does she change her mind about this. Instead of thinking of her own body, she thinks of Bendrix's body:

I thought of certain lines life had put on his face as personal as a line of his writing: I thought of a new scar on his shoulder that wouldn't have been there if once he hadn't tried to protect another man's body from a falling wall. He didn't tell me why he was in hospital those three days: Henry told me. That scar was part of his character as much as his jealousy. And so I thought, do I want that body to be vapour (mine yes, but his?), and I knew I wanted that scar to exist through all eternity. But could my vapour love that

\footnotetext{
${ }^{8}$ Greene, 1951: 93

${ }^{9}$ Graham Greene. The End of the Affair. New York: Penguin Books. p.93

${ }^{10}$ Ibid 20

${ }^{11}$ Graham Greene. The End of the Affair. New York: Penguin Books. p.54

${ }^{12}$ Ibid 87.
} 
scar? Then I began to want my body that I hated, but only because it could love that scar. ${ }^{13}$

His body, which she knows intimately, is represented by this scar, which she views as a physical reminder of Bendrix's essential self. Instead of seeing his scar as one small element of his body, it becomes the central figure of her physical passion. All of Sarah's relationships feature this focus on bodily vulnerability, even her relationship with Henry, which has cooled to a sisterly regard. Sarah comes home in one scene of the novel, prepared to leave Henry for Bendrix. Henry claims to have a headache. Sarah writes, "I came behind him and put my hand on his forehead. It was an odd thing to be doing just before leaving him forever. He used to do that to me when we were first married and I had terrible nervous headaches because nothing was going right. I forgot for a moment that I would only pretend to be cured that way." "When she says, "nothing was going right," she may be discussing the fact that she and Henry have never been sexually compatible, for she tells Bendrix that she never had an orgasm with Henry.

\section{b. Maurice Bendrix growing Obsession with Sarah Miles}

As Graham Greene has pointed out, The End of the Affair has two tones: obsessive love and obsessive hate. The novel features one of Greene's rare food-focused scenes: Bendrix and Sarah go to a film made from one of Bendrix's novels before they begin their affair. The movie is poor, but one scene conveys the contents of the book: one lover refuses to eat onions, because her husband dislikes the taste of them when he kisses her. Bendrix desires Sarah because she identifies this scene, and because she eats her onions with relish even though Henry dislikes them. They order steak at Rules, and Sarah calls it "the best I've ever eaten." 15 They abandon it, however, together in their sexual attraction and purpose: There was no pursuit and no seduction. We left half the good steak on our plates and a third of the bottle of claret and came out into Maiden Lane with the same intention in both our minds. At exactly the same spot as before, by the doorway and the grill, we kissed. I said, 'I'm in love. 'Me too.' ${ }^{16}$. Here in the novel, Maurice Bendrix, Sarah's lover has much thought of Sarah, which justifies his growing obsession toward the wife of his friend (Henry). Just after their meeting in a party, Bendrix's thoughts are full of Sarah when he says: "I've only seen her once since $1944{ }^{17}$ and this has made him lose his identity; loss of his career when he narrates at the beginning of the novel that:

I remember I dreamed a lot of Sarah in in those obscure days or weeks. Sometimes I would wake with a sense of pain, sometimes with pleasure. If a woman is in one's thoughts all day, one should not have to dream of her at night. I was trying to write a book that simply would not come. I did my daily five hundred words, but the characters never began to live. So much in writing depends on the superficiality of one's days. One may be preoccupied with shopping and income tax returns and chance conversations, but the stream of the unconscious continues to flow undisturbed, solving problems, planning ahead: one sits down sterile and dispirited at the desk, and suddenly the words come as though from the air: the situations that seemed blocked in a hopeless impasse move forward: the work has been done while one slept or shopped or talked with friends.

\footnotetext{
${ }^{13}$ Ibid $87-88$.

${ }^{14}$ Ibid 94.

15 (Greene, 1951: 28)

16 (Greene, 1951: 33)

17 (Greene, 1951: 14)
} 
However, this hate and suspicion, this passion to destroy went deeper than the book the unconscious worked on it instead, until one morning I woke up and knew, as though I had planned it overnight, that this day I was going to visit Mr Savage. ${ }^{18}$

It is wise enough to point out that, a lunch meeting with the critic Waterbury demonstrates just how caustic Bendrix can be when he wants. The End of the Affair contains some of Greene's most detailed sexual writing, which is related to the feeling of those who are obsessed in love, and yet when Maurice Bendrix remembers the beginning of his relationship with Sarah Miles, he thinks:

I remember the trivial details very well: how the manageress asked me whether we wanted to stay the night: how the room cost fifteen shillings for a short stay: how the electric meter only took shillings and we hadn't one between us, but I remember nothing elsehow Sarah looked the first time or what we did, except that we were both nervous and made love badly. It did not matter. ${ }^{19}$

Later in the novel, Bendrix demonstrates this even more clearly: "This woman, whom I loved so obsessively that if I woke in the night I immediately found the thought of her in my brain and abandoned sleep seemed to give up all his time to me". Maurice Bendrix is smug. He knows he is smarter than the next man is, and he believes he can get what and whom he wants simply through charm. His intellectual and verbal skills are his defense mechanisms, though just as often they become weapons for attack:

There was never any question in those days of who wanted whom- we were together in desire. Henry had his tray, sitting up against two pillows in his green woolen dressing gown, and in the room below, on the hardwood floor, with a single cushion for support and the door ajar, we made love. When the moment came, I had to put my hand gently over her mouth to deaden that strange sad angry cry of abandonment, for fear Henry should hear it overhead.

Likewise, in The End of the Affair, there is an examination of the virtue of pain and abstinence, as well as the role of sexual love in religious experience is concerned. When the relation between Sarah and Bendrix starts breaking up, and then comes the hate, Bendrix assumes that there is another man. After Sarah ends their relationship, Bendrix suspects that she has a new lover. He hires Parkis, a private investigator, to follow Sarah and report on her activities. Parkis provides the sometimes-bleak narrative with bit of grim comedy, but his role is more than comic relief. Bendrix is intensely interested in the investigator's results, and receives daily reports on what he has found. The summaries give him a new and somewhat exciting perspective on Sarah. Parkis's reports are stilted and self-consciously formal, calling Sarah "the party in question." They translate Sarah's familiar actions and movements into an eerie, abstract series of facts. When Bendrix goes to lunch with Sarah at Rules-the restaurant they frequented when they were a couple-Parkis submits a report, describing the event. It becomes clear that God is the only other man. Sarah ends the affair because she has made a vow: when Bendrix is struck by a V1 bomb during the Blitz, she promises God that if he is alive, she will give him up. She believes him dead, lying unconscious under a door, and she prays for a miracle.

Finally, as we know that, the death of one partner puts an end to obsessive love, it is the same that happens in The End of the Affair meanwhile Sarah's death shocks and devastates Bendrix. He describes his suffering from this loss of a shared history as though it is an injury: "She had lost all our memories for ever, and it was as though by dying she had

18 (Greene, 1951: 37)

19 (Greene, 1951: 37) 
robbed me of part of myself. I was losing my individuality. It was the first stage of my own death, the memories dropping off like gangrened limbs." Bendrix is a person with a considerable store of unpleasantness which has been nurtured by hatred and has been aggravated and stimulated by his frustrated love affair with Sarah, "the sense of unhappiness is so much easier to convey than that of happiness. In misery, we seem aware of our own existence, even though it may be in the form of a Penguin Books. P.113 monstrous egotism; this pain of mine is individual, this . . belongs to me and no other . . . as though I loved in fact what I hate." (Greene, 1951: 47). Bendrix knows he is hateful for he says so frequently, "Hate and suspicion and envy have driven me so far away." (Greene, 1951: 18). However, after Bendrix had Sarah's note informing him she could no longer see him, his hatred becomes a passion. He begins to treat Sarah like a prey. He follows her through London, exulting over her fear. When she dies and his hatred has lost its object he changes it and begins hating God. God had taken his Sarah, he should be hated as bitterly as Henry, and Smythe had been. Bendrix's hatred has left him near insanity and at the end of the novel; he is a near-man. After Bendrix's talk with Henry and the priest, it becomes clear that Greene had intended it this way - Bendrix has been nearly destroyed with hatred and frustrated desire. He rationalises his hatred by declaring it was just to defend him and yet he knew "grief and disappointment are like hate! They make men ugly with selfpity and bitterness" (Greene, 195 78).

Greene's use of Leon Sley's epigraph gives some hint of an explanation into Bendrix's character. "Man has places in his heart which do not yet exist; and into them enters suffering in order that they may have existence" (Ravichand and Parthu, 2013: 411). Through Bendrix's suffering, new ideas come to life. Once the rage was over, Bendrix was certainly a wiser man than he had been before it started. Bendrix with the avowed purpose of doing research on Henry for the future novel about civil servants falls in love with Sarah. This love leads to an affair, which goes on despite Henry Miles, a trusting and bright husband, until a bomb strikes Bendrix's apartment house and injures him. Sarah, who was present, believing that Maurice has been killed, she turns for the first time to God, and vows to surrender Bendrix if only his life is spared. He is not dead and so begins the process of her subjection to the love of the Hound of Heaven.

\subsection{Criticism on Mr. Greene's View of Obsessive Love through The End of the Affair}

The theme of this novel is the wrestling with the love and grace of God of a very ordinary man and an apparently completely pagan woman, but one with immense spiritual potentialities. It is not the story of sanctity through adultery, it is the story of a woman torn between two loves, and it is told in terms of Greene's view of reality. The sexual relationship between Maurice Bendrix and Sarah Miles is the subject of Sarah's bargain with God in The End of the Affair. In every case, sex connects the other themes of the novel: religion, political engagement, commitment etc. Erotic love becomes the animating force of the book, just as it is the source of Sarah Miles's spiritual desire in The End of the Affair. Despite the shakiness of her faith, she obeys her vow, and she ends their liaison. Bendrix does not understand why until the middle of the book, when he reads Sarah's diary, which constitutes the center of the novel.

In his "Introduction to the New Penguin Classics edition of The End of the Affair", Michael Gorra writes that the diary provides "the core of the novel's critical interest," as well as its most "memorable" voice (Gorra, 2004: 19). Her narrative stands alone in a number of ways. In The End of the Affair, Greene takes up for the first and essentially only 
time the task of writing in a female voice. Her impassioned, wide-ranging meditation encompasses religion, sexuality, and the pain of loss. As she adheres to her vow, she asks herself whether she could love or understand God without first having loved Bendrix. Sarah's narrative describes via negativa of her religious faith: she comes to God only by her own suffering and abstinence. She writes at length about the experiences of her body as they relate to the suffering of Christ, and she argues that her union with Bendrix opened her up for the development of faith.

As Mark Bosco argues, Greene proposes to place the doctrine of the incarnation at the center of his realistic novel, thereby pushing the ramifications of the doctrine to extreme moments of sexual ecstasy and of intense suffering because of the loss of the beloved's body. If God has become human flesh, the logic goes, and then every finite body is a possible conduit of God's grace (Mark Bosco cited in Ravichand and Parthu, 2013: 411).

There is always the idea of the double man in Greene, "There's another man within me that's angry with me"; there is always this duality in man's nature that Greene is concerned with. With Sarah it is the duality of the known physical desire and the unknown spiritual love fighting for supremacy of her soul. The End of the Affair, however, reverts to "type" in its portrayal of Greene's obsession. Greene once wrote that every creative writer must have an obsession and up to Brighton Rock (1938), his has been with failure, but in The End of the Affair, his obsession has changed to hatred. This novel is heavy with hatred and it is probable that it was a product of some personal crisis. Hatred is one of the escape valves through which Greene's intense feelings escape. Greene, through the medium of his novelist-character Bendrix, writes out of bitter hatred. "What a dull, lifeless quality this bitter hatred is. If I could write with love, but if I could write with love, I would be another man: I would never have lost love". Nevertheless, not all of Bendrix's bitterness comes from hatred; some of it comes from frustrated love.

\section{Conclusion}

Our daily events have been once again revealed in Graham Greene's The End of the Affair through his imaginative construction. Novels revolve around discussion and confession, whether love or other issues. The End of the Affair shows the nuances, complexities, depths and strengths of love, how, serious, dynamic, and mighty it is, while also showing how selfish it is and one cannot really have love without hate. One of the issues depicted in the novel is the growing obsession between three central characters: The writer Maurice Bendrix; Sarah Miles; and her husband, Henry Miles.

From my literature review until my conceptual clarification, I have found that love has two facets: true love and obsessive love. True or healthy love is based on the emotion or feeling. The obsessive love is a condition in which one person feels an overwhelming obsessive desire to possess another person toward whom one feels a strong attraction, with an inability to accept failure or rejection. Likewise, this obsessive love has four phases: the attraction phase, the anxious phase, the obsessive phase and finally the destruction phase. Thus, as I have pointed out in chapter three of my research work, I have discovered that some interests one sees in another partner cause obsessive love. This is manifested through the desire in someone to be with his/her partner every time. Finally, it has some consequences on the obsessive lover through which death can follow. In The End of the Affair, Greene explores the connections between male-female friendship and sexual relationships. I have found that the growing obsession among the central characters is 
manifested throughout the novel. The End of the Affair is full of examination of a three-way collision between love of self, love of another, and love of God. The End of the Affair does not involve a love triangle; it involves a love among four lovers; the four lovers being Sarah Miles, her husband Henry, Maurice Bendrix and God. Thinking that Bendrix has been killed, Sarah, who is an agnostic, sinks to her knees and promises God that if Bendrix lives she will give him up. She is indeed involved with another lover for whom she has left Bendrix: God. She rationalises that if God does not really exist then she is free to do as she pleases. In order to try to convince herself of God's non-existence, she begins studying with a notorious atheist intellectual. Unfortunately, atheist arguments against the existence of God only convince Sarah that God is real and that she must keep her promise. After finding out that his girlfriend left him for God, who then proceeded to take her away permanently, Bendrix, who has been an atheist, hates God. Bendrix realizes that he cannot hate God and remain an atheist since hate is just the other side of love. In order to hate God, Bendrix must first believe in Him. A big theme of The End of the Affair is the nature of faith.

Finally, I can say that Love is based on respect, trust, deep friendship and real communication and realistic expectations whereas obsession is like an addiction. In addition, that obsession can lead the one who is obsessed in a dangerous life that could be ended by death.

\section{References}

Corneille P. (1937). le Cid, France.

D H Lawrence. (1913). sons and Lovers, B.W. Huebsch Publishers.

Raoufzadeh, N., Hosein, S. M., \& Birgani, S.Z. Analysis of Love, Death, Rebirth and

Patriarchy in Two Contemporary Poetess Forough Farrokhzad and Sylvia Plath's

Selected Poems. Budapest International Research and Critics Institute (BIRCIJournal), 56-64.

Shakespeare W. (1595). Romeo and Juliette, UK.

Tetty Betty. (2019). Love in English for Students, n.d., https://www.english-for students.com/love.2.html (consulted on August 2, 2019 at 10 a.m.) 